Олександр РУДЕНКО, orcid.org/0000-0002-0368-6445 викладач кафедри хорового диригування, вокалу та методики музичного навчання Сумського державного педагогічного університету імені А. С. Макаренка (Суми, Україна) sasha798132@gmail.com

\title{
ВПЛИВ ТВОРЧОЇ СПІВПРАЦІ НА КОМПОЗИТОРСЬКУ ПРАКТИКУ В. ГУБАРЕНКА ДРУГОЇ ПОЛОВИНИ ХХ СТОЛІТТЯ
}

\begin{abstract}
У дослідженні вперше встановлюються взаємозв'язки між творчим спілкуванням В. Губаренка з відомими украйнськими виконавцяяи та створенням ним оригінальних творів. Проведено стислий огляд процесу становлення В. Губаренка як композитора, розглянуто його композиторську та виконавську діяльність. Вказано, щзо слово мития вирізнялося сучасністю та оригінальністю музичної мови, пошуками нових форм $і$ нестандартними рішеннями при створенні образів. Творчості мития притаманне нестримне бажання відображати оточуючу дійсність, пропускаючи ї̈ крізь власні почуття та розуміння. Саме такий підхід допоміг композитору створити твори, насичені яскравою емочійністю та справжньою силою почуттів.

Одним із перших музичних жанрів, у яких творив композитор, були романси, невеликі хорові твори, інструментальні балади та поеми. Перші романси були створені в учбові роки та виконані товаришами В. Губаренка по консерваторії- С. Івановим і В. Валайтісом. Така взаємодія з часом трансформувалася у необхідність постійної співпраці з виконавцями і керівниками музичних колективів. Сам В. Губаренко вважав ї̈ основоположним принципом, композиторським стимулом і творчою необхідністю.

Іншими музикантами, з якими В. Губаренка звела творча доля, були Є. Мирошніченко, Г. Авер'янов, О. Кудряшов, О. Пархоменко. Кожне знайомство мало результативні творчі діі. Таким чином були створені концертпоема для віолончелі з оркестром, кониерт для флейти з оркестром, камерна симфонія для скрипки з оркестром. Наголошено, щзо під час співпраці митецьь намагався створити ичікаві драматургічні, композиційні та ансамблеві рімення для висвітлення максимальних можливостей солюючих інструментів та оркестру. Визначено, щзо творча доля В. Губаренка час від часу була тісно пов 'язана зі знайомствами і спілкуванням з видатними украӥнськими виконавиями та диригентами світової сцени. Ця плідна співпрачя послугувала поштовхом для появи національних творів украӥнської академічної сцени.
\end{abstract}

Ключові слова: В. Губаренко, вокальна творчість, композиція, украйнська музична культура, виконавське мистеитво.

Oleksandr RUDENKO, orcid.org/0000-0002-0368-6445

Lecturer at the Department of Choral Conducting, Vocal and Methods of Musical Education Sumy State Pedagogical University named after A. S. Makarenko (Sumy, Ukraine) sasha798132@gmail.com

\section{THE INFLUENCE OF CREATIVE COOPERATION ON V. HUBARENKO'S COMPOSITORY PRACTICE OF THE SECOND HALF OF THE XX CENTURY}

The study for the first time establishes the relationship between the creative communication of $V$. Hubarenko with famous Ukrainian artists and the creation of original works. A brief overview of the life of $V$. Hubarenko as a composer is made, the composer's and performer's activity is considered. It is stated that the artistic word of the artist differed in modernity and originality of musical language, search for new forms and most importantly - non-standard solutions in creating images of selected characters. The artist's work is characterized by an uncontrollable desire to reflect the surrounding reality, passing it through their own feelings and understandings. It is this approach that helped the composer to create works full of vivid emotions and true power of feelings.

One of the first musical genres in which the composer worked was romances, small choral works, instrumental ballads and poems. It is noted that the first romances were created during the school years and performed by V. Hubarenko's friends at the conservatory - E. Ivanov and V. Valaitis. Such interaction over time was transformed into the need for constant cooperation with performers and leaders of musical groups. V. Hubarenko himself considered this as a fundamental principle, a composer's stimulus and a creative necessity.

Other musicians with whom V. Hubarenko had a creative destiny were E. Myroshnichenko, G. Averyanov, O. Kudryashov, O. Parkhomenko. Each acquaintance had effective creative actions. Thus were created the Concert-poem for cello and 
orchestra, the Concerto for flute and orchestra, the Chamber Symphony for violin and orchestra. It is emphasized that during the collaboration the artist tried to create interesting dramatic, compositional and ensemble solutions to highlight the maximum possibilities of solo instruments and orchestra. As a result, it was determined that the creative destiny of V. Hubarenko from time to time was closely connected with acquaintance and communication with prominent Ukrainian performers and conductors of the world stage. This fruitful cooperation served as an impetus for the emergence of national works of the Ukrainian academic scene.

Key words: V. Hubarenko's, vocal creativity, Ukraine musical culture, performing arts.

Постановка проблеми. Українська музична культура другої половини XX століття характеризується новою хвилею розквіту різних стильових течій. Не дивлячись на продовження ідеологічної цензури у сфері мистецтва, цей період характеризується різноманітністю поглядів, активним пошуком нового музичного висловлення та втіленням нових художніх ідей.

Одним із молодих композиторів цього часу, чия творчість мала великий вплив на подальший розвиток української музики другої половини XX століття, був Віталій Губаренко. Творчості митця притаманне нестримне бажання відображати оточуючу дійсність, пропускаючи іiі крізь власні почуття та розуміння. Саме такий підхід допоміг композитору створити твори, насичені яскравою емоційністю та справжньою силою почуттів.

Музична творчість В. Губаренка характеризується пошуками нових засобів виразності та розширенням інтонаційної сфери вокального виконавства. У більшості творів сучасної наукової літератури розкривається творчість зрілого та пізнього періоду композитора. Питання ж співпраці В. Губаренка із виконавцями та вплив такої взаємодії на творчі досягнення митця є мало розробленою темою в українському музикознавстві, що й зумовлює актуальність цієї роботи.

Аналіз досліджень. Творчість В. Губаренка привертає увагу багатьох науковців своєю самобутністю та оригінальністю. Одними з грунтовних праць, присвячених долі композитора, є монографія I. Драч (Драч, 2002) та робота Е. Яворського (Яворський, 1971). Інструментальну та вокальну творчість митця розглядають у своїх роботах В. Жадько, А. Муха, Л. Кияновська, Т. Краснопольська, М. Черкашина-Губаренко. Однак розробок щодо висвітлення творчої роботи композитора з виконавцями не досить.

Мета статті - розкрити особливості творчої взаємодії В. Губаренка з виконавцями та її вплив на композиторську діяльність митця. Для розкриття характерних рис композиторської творчості та особливостей виконавської інтерпретації у творах В. Губаренка у статті використано методи теоретичного узагальнення та методичного аналізу. Виявлення стильових особливостей, художньо-образного змісту, структури, виразових і технічних засобів твору здійснено за допомогою теоретичного та виконавського аналізу.

Виклад основного матеріалу. Чи не найважливішою подією в Україні другої половини $\mathrm{XX}$ століття стає тимчасова лібералізація у суспільстві. Внаслідок цього поступово з'являється нове покоління талановитих діячів мистецтва та культури. Повертається нове покоління діячів мистецтв: М. Виноградовський, Е. Гуцало, I. Драч, Р. Іваничук, В. Коротич, Д. Павличко, М. Руденко, А. Симоненко, В. Шевчук та інші. У музичному мистецтві зростає нова хвиля зацікавлення творчістю С. Людкевича, Г. і П. Майбород, Л. Ревуцького, Ю. Мейтуса, А. Штогаренка, А. Кос-Анатольського. Стають популярними твори О. Білаша, А. Філіпенка, І. Шамо.

Творчість молодого представника Харківської композиторської школи В. Губаренка стала частиною цього напряму на початку 1960 -х років. Його мистецьке слово вирізнялося сучасністю та оригінальністю музичної мови, пошуками нових форм і нестандартними рішеннями при створенні образів головних героїв. До улюблених жанрів композитора можна віднести оперу, балет, симфонії, концертні твори для оркестру 3 солюючими інструментами, музику до спектаклів і вокальні цикли.

У час так званої «відлиги» хоча контроль $\mathrm{i}$ послабився, але про повну свободу творчості не йшлося. Політична цензура постійно закликала рухатися тільки у спланованому напрямі. Композиторам того часу найчастіше залишалася можливість обирати власні зображальні методи, демонструвати свою музичну мову, але у загальноприйнятій політичній канві. Як писала видатний український музикознавець I. Драч, «Губаренко обирає за основу власної музичної мови вільно трансформовані і психологічно укрупнені елементи української (у тому числі західноукраїнської) пісенності» (Драч, 2002: 39). Сучасник композитора, український музикознавець Н. Некрасова так змальовувала його: «Український композитор Віталій Губаренко - художник сучасний і типово національний. Актуальність тем і задумок, нестандартність форм, новизна засобів музичної виразності - усе це безумовні атрибути сучасного мистецтва» (Некрасова, 1976: 1). 
Дитинство В. Губаренка проходило у різних містах: Західна Україна (Коломия, Снятин, ІваноФранківськ), казахстанське місто Зайсан, знову Харків і Західна Україна. Більш-менш професійно займатися музикою він почав досить пізно - приблизно 312 років при різних музичних школах будинках культури. Незважаючи на це, він самостійно приймає рішення та вступає на навчання до теоретичного відділу Харківського музичного училища. Першим учителем композиції був Олександр Жук - харківський композитор і диригент (1907-1995 pp). Він систематизував існуючі початкові знання і навички молодого музиканта та допоміг йому отримати грунтовну теоретичну базу.

Після закінчення Харківської консерваторії В. Губаренко залишився в закладі на посаді викладача. Під час Другої світової війни, у часи окупації Харкова він був диригентом Харківського драматичного театру імені Т. Г. Шевченка. На прикладі композиторської діяльності наставника В. Губаренко звертається до таких жанрів як інструментальна балада та поема, романси та хорові ансамблі. За підтримки вчителя з-під пера майбутнього відомого композитора вийшли «Балада» для віолончелі «Думка» для фортепіано, «Поема» для скрипки 3 фортепіано, хорові твори «Тече вода» на слова Т. Шевченка, «Стояла я і слухала весну» на слова Лесі Українки, «Осінь» на слова О. Пушкіна, «Прості» на слова М. Лермонтова та інші.

Розвиток композиційної майстерності відбувався у традиційній системі вивчення та створення творів: від малих форм до великих. Таким чином музичне навчання не зводилося до банального викладення та заучування матеріалу, а відбувався систематичний творчий розвиток умінь і художніх смаків, які потім було покладено в основу діяльності уславленого композитора. В. Губаренко завжди вирізнявся завзятою наполегливістю, тому заняття композицією не завадило йому брати активну участь у роботі хорового колективу «трудових резервів» під керівництвом композитора й хормейстера 3. Заграничного. На той час у складі хору виступала молода артистка, «соловейко» українського вокального мистецтва - Є. Мирошниченко. Їхнє знайомство у майбутньому сприяло появі відомої моноопери для високого голосу «Листи кохання» за мотивами новели Анрі Барбюса «Ніжність» (1971 рік).

Продовжуючи навчання у Харківській консерваторії, В. Губаренко під керівництвом Д. Клебанова постійно відшліфовує композиторську майстерність. У цей час митець найчастіше звертається до вокальних жанрів, що зумовлювалося як учбовою програмою, так і власним зацікавленням вокальним мистецтвом. Ще одним важливим чинником, який вплинув на звернення композитора до камерно-вокальних жанрів, було знайомство та дружба із С. Івановим - майбутнім солістом Одеського театру опери та балету. Саме йому було присвячено романси «Дуб» на слова М. Ісаковського та «Жебрак» на слова М. Лермонтова.

Іншим виконавцем зазначених вище романсів і товаришем по консерваторії був В. Валайтіс, який згодом став солістом Великого театру. Така взаємодія 3 часом трансформувалася у необхідність постійної співпраці з виконавцями та керівниками музичних колективів. Сам В. Губаренко вважав іiі основоположним принципом, композиторським стимулом і творчою необхідністю. Варто зазначити, що це стосується і всіх інших жанрів, у яких працював композитор.

Під час подальшого навчання у консерваторії відбувається знайомство 3 творчістю молодого викладача та віолончеліста Г. Авер'янова, який нещодавно закінчив аспірантуру у Києві. Сучасники Г. Авер'янова зазначали, що він володів співучим, насиченим і різнобарвним звуком. Вражений виступом артиста, В. Губаренко починає роботу над концертом-поемою для віолончелі 3 оркестром (1963 рік). Під час роботи над твором Г. Авер'янов постійно надавав В. Губаренку цінні поради стосовно технічних можливостей віолончелі, виконавсько-технічних особливостей i тембрової колористики. По закінченні твору Г. Авер'янов редагував віолончельну партію та став першим іiі виконавцем. Не можна не згадати і виконавську діяльність В. Фейгіна, у репертуарі якого постійно була ця концертна поема.

1965 рік ознаменується появою Концерту для флейти та оркестру (1963 рік). Історія створення цього твору починається зі знайомства 3 солістом Державного симфонічного оркестру України, заслуженим артистом УРСР О. Кудряшовим. Виконавська майстерність флейтиста удосконалювалася під керуванням кращих представників французької флейтової школи. У подальшому О. Кудряшов мав величезний успіх у Парижі, Гельсінкі та багатьох інших містах. У своєму останньому інтерв'ю телеканалу «Культура» під назвою «Флейта Олега Кудряшова» (2016 рік) маестро розповідає про особливості навчання у Празькій консерваторії та подальшу творчу діяльність (Флейта, ЕР).

Передивляючись концертні виступи маестро, не можна не звернути увагу на красу та багатство тембрового забарвлення голосу О. Кудряшова, його емоційну насиченість, багатство нюансів i теплоту звучання. Він ніби спростовує усталену думку про характерне та специфічне звучання цього інструменту. 
Зустріч із О. Кудряшовим вплинула на рішення В. Губаренка створити Концерт для флейти 3 оркестром. Композитор використав майже всі можливості цього інструменту. Сумна лірика першого повільного розділу співставляється 3 віртуозним рухом мелодії та танцювальними наспівами другого розділу. Ці розділи Andante та Allegro graciozo об'єднує використання однієї музичної теми, яка пронизана національним мелодичним звучанням та використанням інтонацій західноукраїнського фольклору. Цікаво і те, що флейта не є домінуючим інструментом, хоча саме їй доручена експозиція усіх музичних тем твору. Внаслідок співставлення лірика остаточно перемагає й у заключному епізоді, в якому знову повертається перша тема 3 Andante. Дебют концерту був дуже успішним, що підтверджує його подальше виконання у Києві, Донецьку, Харкові та інших містах України.

Знайомство та співпраця з відомою скрипалькою О. Пархоменко вплинуло на створення композитором Камерної симфонії для скрипки 3 оркестром (1978 рік). О. Пархоменко постійно наголошувала на необхідності появи симфонічного твору такого типу, у якому б відчувався національний колорит i який би був створений саме українським композитором. Перше виконання камерної симфонії відбулося у залі Харківської філармонії 3 березня 1968 року. На превеликий жаль, науковцями не досліджено подальшу співпрацю 3 відомою скрипалькою та особливості її трактовки твору.

Про давню дружбу з С. Турчаком свідчить той факт, що Друга симфонія В. Губаренка (1965 рік) була присвячена саме йому та оркестру під його орудою. Твір 3 великим успіхом було виконано у багатьох містах, а у рідному Харкові він прозвучав під керівництвом І. Шпіллера. Цікаво, що прем'єра симфонії відбулася в Донецьку у виконанні симфонічного оркестру Донецької філармонії під керівництвом Г. Проваторова - головного диригента Одеського театру опери та балету і товариша В. Губаренка по Харківській консерваторії.

З 1972 року В. Губаренко повністю переходить на суто композиторську діяльність, але твори композитора вже міцно увійшли в концертний репертуар таких провідних диригентів: Г. Проваторова, С. Турчака, П. Шемета, В. Гнедаша та багатьох інших. В. Губаренку часто таланило на професійну підтримку відомих диригентів. Серед тих, хто активно популяризував творчість композитора, був Н. Рохлін - головний диригент Державного академічного симфонічного оркестру України. Він усіляко сприяв закріпленню творів В. Губаренка у репертуарі колективу, а С. Турчак у подальшому підхопив диригентську естафету цього оркестру й підготував низку прем'єр композитора, серед яких булиопери «Загибельескадри» (1965рік)та «Мамаї» (1969 рік), балет «Кам’яний господар» (1968 рік).

Не можна не згадати і художнього керівника та головного диригента Заслуженого академічного симфонічного оркестру Національної радіокомпанії України, а згодом художнього керівника та головного диригента Національного заслуженого академічного симфонічного оркестру України В. Сіренка. Саме під його орудою були поставлені остання симфонія "De Profundis" (1996 рік), симфонії, балети та хореографічні сцени за однойменною повістю М. Гоголя «Вій» (2000 рік).

Висновки. Творча доля В. Губаренка була щільно пов'язана зі знайомствами та спілкуванням із видатними українськими виконавцями та диригентами світової сцени. Плідна співпраця композитора 3 О. Кудряшовим, С. Турчаком, О. Пархомчук та іншими діячами послугувала поштовхом для появи національних творів української академічної сцени.

Перспективність більш глибокого вивчення творчого спадку В. Губаренка та з'ясування поставлених питань $є$ завданням для подальших наукових розвідок.

\section{СПИСОК ВИКОРИСТАНИХ ДЖЕРЕЛ}

1. Віталій Губаренко: сторінки творчості. Статті, дослідження, спогади. Науковий вісник Національної музичноі академії Украӥни ім. П. І. Чайковського. Книга 4. До 90-річчя Національної музичної академії України ім. П. І. Чайковського. Київ, 2003. Випуск 32. С. 6.

2. Гордейчук Н. Осуществленные надежды. «Советская музыка», 1969. № 9. С. 11.

3. Драч I. Вокальна лірика Віталія Губаренка. Наукові записки Тернопільського педагогічного університету. № 1 (2). Тернопіль : ТДПУ, 1999.

4. Драч I. Композитор Віталій Губаренко: формула індивідуальності : монографія. Суми : Сумський державний педагогічний університет ім. А. С. Макаренка, 2002. 228 с.

5. Некрасова Н. Очерк о творчестве В. Губаренко. Композиторы союзных республик. Москва : Советский композитор, 1976. Вып. 1. С. 1.

6. ПолянськаГ. М. Симфонія-балет «Зелені святки» Віталія Губаренка. Українське музикознавство. Вип. 30. Київ, 2001.

7. Флейта Олега Кудряшова : інтерв’ю [Електронний ресурc]. URL: https://www.youtube.com/watch?v=kq1Ccn82Fog\& ab channel= $\%$ D0 $\% 96 \%$ D0\%B0\%D0\%BD $\%$ D0\%BD $\%$ D0 $\%$ B0\%D0\%91\%D0\%B5\%D0\%B1\%D0\%B5\%D1\%88\%D0\%BA $\% \overline{\mathrm{D}} 0 \% \mathrm{BE} \% \mathrm{D} 1 \% 80 \% \mathrm{D} 0 \% \mathrm{~B} 5 \% \mathrm{D} 0 \% \mathrm{~B} 6 \% \mathrm{D} 0 \% \mathrm{~B} 8 \% \mathrm{D} 1 \% 81 \% \mathrm{D} 1 \% 81 \% \mathrm{D} 1 \% 91 \% \mathrm{D} 1 \% 80$ (дата звернення: 10.12.2020).

8. Яворський Е. Віталій Губаренко. Київ : Музична Україна, 1971. 50 с. 


\section{REFERENCES}

1. Vitalii Hubarenko (2003): Storinky Tvorchosti. Statti, Doslidzhennia, Spohady. Naukovyi Visnyk Natsionalnoi Muzychnoi Akademii Ukrainy imeni P. I. Chaikovskoho. [Vitaliy Hubarenko: Pages of creativity. Articles, research, memoirs]. Book 4. Kyiv, Vol. 32. P. 6 [in Ukrainian].

2. Gordeichuk N. (1969). Osushchestvlennye Nadezhdy [Fulfilled hopes]. Issue 9. P. 11 [in Russian].

3. Drach I. (1999). Vokalna Liryka Vitaliia Hubarenka. Naukovi Zapysky Ternopilskoho Pedahohichnoho Universytetu [Vitaly Lyrics by Vitaliy Hubarenko]. Ternopil [in Ukrainian].

4. Drach I. (2002). Kompozytor Vitalii Hubarenko: Formula Indyvidualnosti : monografiia [Composer Vitaliy Gubarenko: Formula of indivisibility : monograph]. Sumy : Sumy A. S. Makarenko State Pedagogical university. 228 p. [in Ukrainian].

5. Nekrasova N. (1976). Ocherk O Tvorchestve V. Hubarenko. Composers of the union republics. [Essay on the work of V. Gubarenko]. Moscow : Sovetskii kompozitor. Issue 32. P. 2 [in Russian].

6. Polianska H. M. (2001). Symfoniia-Balet "Zeleni Sviatky" Vitaliia Hubarenka. Ukrainske Muzykoznavstvo. [Vitaly Hubarenko's symphony-ballet "Green Holidays"]. Issue 30. Kyiv [in Ukrainian].

7. Fleita Oleha Kudriashova : Interviu [Flute by Oleg Kudryashov : interview]. (2016). URL: https://www.youtube.com/ watch? $\mathrm{v}=\mathrm{kq} 1 \mathrm{Ccn} 82 \mathrm{Fog} \& \mathrm{ab}$ channel= $\% \mathrm{D} 0 \% 96 \% \mathrm{D} 0 \% \mathrm{~B} 0 \% \mathrm{D} 0 \% \mathrm{BD} \% \mathrm{D} 0 \% \mathrm{BD} \% \mathrm{D} 0 \% \mathrm{~B} 0 \% \mathrm{D} 0 \% 91 \% \mathrm{D} 0 \% \mathrm{~B} 5 \% \mathrm{D} 0 \% \mathrm{~B} 1 \%$ D0\%B5\%D1\%88\%D0\%BA\%D0\%BE\%D1\%80\%D0\%B5\%D0\%B6\%D0\%B8\%D1\%81\%D1\%81\%D1\%91\%D1\%80 (Last accessed: 10.12.2020).

8. Yavorskyi E. (1971). Vitalii Hubarenko [Vitaly Hubarenko]. Kyiv : Muzychna Ukraina. P. 17 [in Ukrainian]. 